Caradoc (Martin 1968; Vavrdova 1965). Another feature is the occurrence of a specimen compared with $B$. granulatispinosum; this is essentially a Silurian form, although Vavrdova (1965) has a record of it from the Ashgill of Bohemia.

\title{
REFERENCES
}

DEUNFF, J. 1958. Micro-organismes planctoniques du Primaire armoricain. 1. Ordovicien du Veryhac'h (Presqu' lle de Crozon). Bull. Soc. géol. minér. Bretagne, (N.S.) $2: 1-41,2$ pls.

DINES, H. G., HOLMES, S. C. A. \& ROBBIE, J. A. 1954. Geology of the Country around Chatham. Mem. geol. Surv. U.K. ii-viii, $1-157$, pls. $1-5$.

EISENACK, A. 1931. Neue Mikrofossilien des baltischen Silurs. I. Paläont. Zh. 13 : $74-118$, pls. $1-5$.

HENRY, J. L. 1959. Micro-organismes incertae sedis (acritarches et chitinozoaires) de l'Ordovicien de la presqu' Île de Crozon (Finistère) gisements de Mort-Anglais et de Kerglintin. Bull. Soc. géol. minér. Bretagne, (N.S.) : 63-100, 13 pls.

JANSONIUS, J. 1964. Morphology and classification of some chitinozoa. Bull. Can. petrol. Geol. 12, (4) : 901-18, pls. 1-2.

JENKINS, W. A. M. 1967. Ordovician chitinozoa from Shropshire. Palaeontology 10 : $436-88$, pls. $68-75$.

LAMPLUGH, G. W., KITCHIN, F. L. \& PRINGLE, J. 1923. The concealed Mesozoic rocks in Kent. Mem. geol. Surv. U.K. : 1-249, pls. 1, 2.

LAUFELD, S. 1967. Caradocian chitinozoa from Dalarna, Sweden. Geol. För. Stockh. Föhr. $89: 273-349$.

MARTIN, F. 1968. Les acritarches de 1'Ordovicien et du Silurien Belges. Mem. Inst. roy. Sci. nat. Belg. $160: 1-175,8$ pls.

STAPLIN, F. L., JANSONIUS, J. \& POCOCK, S. A. J. 1965. Evaluation of some acritarchous hystrichosphere genera. Neues Jb. Miner. Geol. Palaönt. Abh. 123 : 167-201, pls. $18-20$.

TWENHOFEL, W. H. 1928. Geology of Anticosti Island. Mem. geol. Surv. Brch Can. $154: 1-481$, pls. $1-60$.

VAVRDQVA, M. 1965. Ordovician acritarchs from Central Bohemia. Věst. ústředr. Ust. geol. $40: 351-7$, pls. $1-4$.

WITHERS, T. H. 1926. Catalogue of the Machaeridia (Turrilepas and its allies). Brit. Mus. (Nat. Hist.), London.

INSTITUTE OF GEOLOGICAL SCIENCES, RING ROAD, HALTON, LEEDS 15.

DEPARTMENT OF PALAEONTOLOGY,

BRITISH MUSEUM (NATURAL HISTORY), LONDON, S.W.7.

INSTITUTE OF GEOLOGICAL SCIENCES, LONDON, S.W.7.

T. R. LISTER

L. R. M. COCKS

A. W. A. RUSHTON

10th November, 1969.

\section{LONGVILLIAN SHELLY FAUNAS FROM THE DOLWYDDELAN AREA, NORTH WALES}

SIR,-We would like to present results of recent work on the shelly faunas from sediments immediately underlying the Snowdon Volcanic Series in the Dolwyddelan area. The detailed stratigraphy of the Dolwyddelan area was first investigated by Williams \& Bulman (1931). They suggested that the Snowdon Volcanic Series in the Dolwyddelan syncline consisted of the Lower Rhyolite Tuffs at the base succeeded by the Bedded Pyroclastic Series and the Upper Rhyolite Tuffs. Black slates assigned to the 


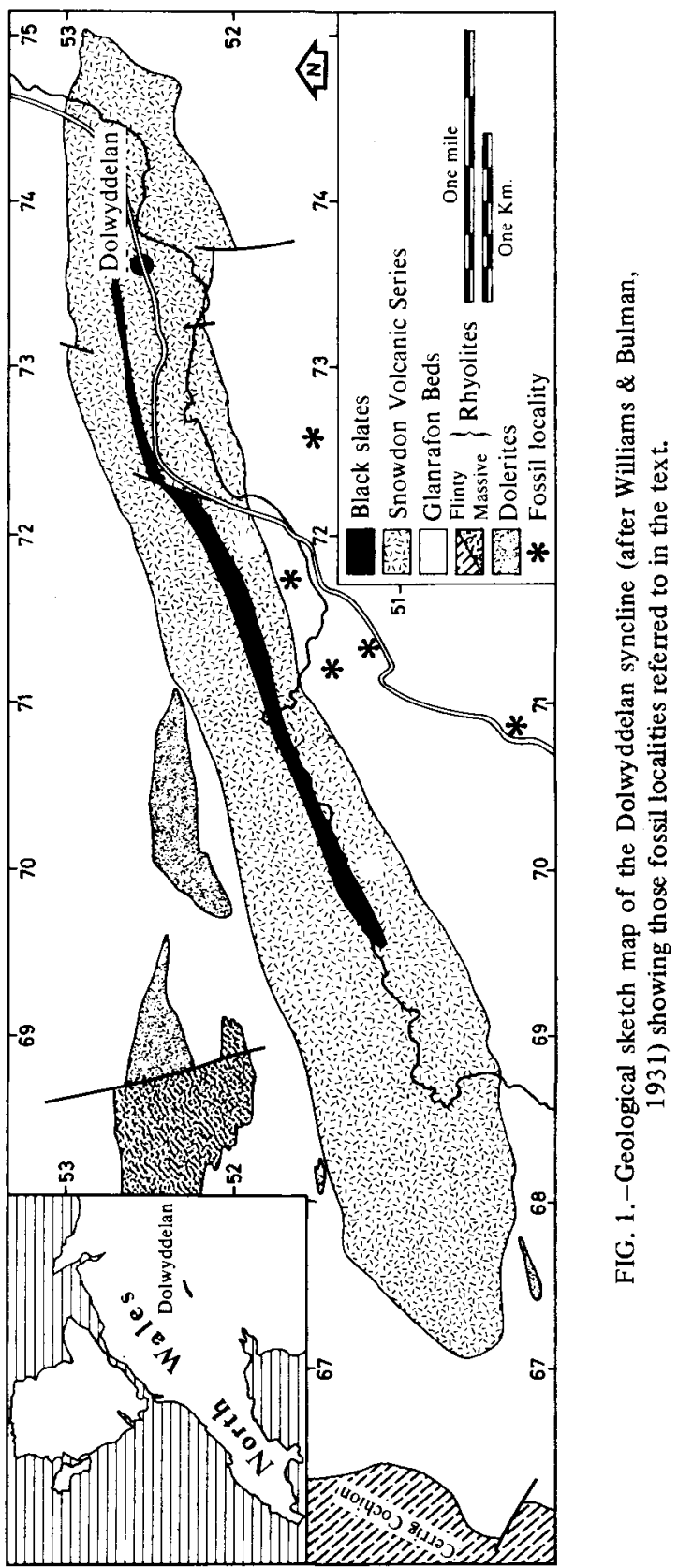


Dicranograptus clingani Zone were found to overlie the Snowdon Volcanic Series. Williams \& Bulman were unable to find a satisfactory fauna in the Glanrafon Beds underlying the Snowdon Volcanic Series which would place these sediments in an accurate stratigraphic position owing to the 'dubious long-range species' but they thought that the presence of a trilobite resembling Homalonotus bisulcatus M'Coy and Sowerbyella sericed var. soudleyensis Jones suggested that the Glanrafon Beds were Middle Caradoc in age or sligh tly older (Williams \& Bulman 1931, p. 431).

Although fossils occur throughout much of the Glanrafon Beds in this area, only the richer localities are considered here. It was found that faunas were most abundant and better preserved in the more arenaceous horizons, and so the majority of faunas discussed here have been obtained from such beds. Grid references are given for localities mentioned below.

Dalmanellids and Sowerbyella spp? were found at most localities and are locally abundant, with either group being dominant. It was not found possible to classify the two groups to specific level with any degree of certainty. As the speciation of these brachiopods is now based largely on statistical methods (Williams, 1963) the authors found it very difficult to obtain a satisfactory statistical comparison of the Dolwyddelan forms with those redescribed by Williams, owing to the deformed nature of the specimens and their sometimes imperfect preservation. Crinoid fragments and occasional cystoid plates were found at all these localities. Wherever possible we have correlated the faunas below with those of the Bala area to avoid any problems of diachronism of the faunas between Snowdonia and south Shropshire.

At SH 71465117 (Fig. 1) we found: Broeggerolithus nicholsoni (Reed), Flexicalymene planimarginata (Reed), $F$. cf. caractaci (Salter), Bicuspina $\mathrm{cf}$. spiriferoides (M'Coy), Dinorthis sp. and a bellerophontid. B. nicholsoni, $F$. cf. caractaci and $F$. planimarginata appear to be mainly restricted to the Longvillian Stage (Dean, 1963, p. 15-16 and Whittington, 1968 , p. III) although $F$. planimarginata is recorded from the upper Soudleyan in Shelve (Dean in Whittard, 1967, p. 320). The only brachiopod from this locality which was identifiable at specific level ( $B$. cf. spiriferoides) has a range from Middle Soudley an to Longvillian although at Bala (Williams, 1963, p. 335) 'it is generally supposed to be pre-eminently characteristic of the Longvillian stage' (op. cit., p. 425). On balance a Longvillian age for this locality seems most likely. Approximately $1 \frac{114}{\mathrm{~km}}$ east-northeast along the strike at SH 72635150 a smaller fauna was found containing B. ?nicholsoni, F. planimarginata and Dinorthis cf. berwynensis (Whittington). D. berwynensis at Bala (Williams, 1963, p. 335, 340) is restricted to the Soudley an Stage while its subspecies $D$. berwynensis angusta Williams is found in the Gelli-grin Calcareous Ashes (Longvillian) and upper Allt Ddu Group (Soudleyan). Although the evidence is poor, a Longvillian age is also suggested for this fauna.

Slightly higher up in the succession, similar faunas were found at SH 71785163 and SH 71225136 . The faunas found at SH 71785163 include: $B$. nicholsoni, Brongniartella sp. indet., ?Kloucekia sp. indet. and Isotelinid gen. et sp. indet. At SH 71225136 the following are present: $B$. nicholsoni, $F$, planimarginata, $K$. apiculata (M'Coy) and Isotelenid gen. indet. cf. powisi (Murchison). The presence of $B$. nicholsoni indicates a Longvillian age and this is supported by the occurrence of $F$. planimarginata and $K$. apiculate. Isotelenid gen. indet. cf. powisi has been recorded only from the Soudleyan Stage at Bala although Isotelenid gen. indet., a form resembling cf. powisi in its cranidium and hypostome, is fairly common in the Gelli-grîn Calcareous Ashes (Whittington, 1966, p. 77). The faunas from these two localities are the stratigraphically highest that we have found in the sediments below the Snowdon Volcanic Series at Dolwyddelan and although the evidence is inconclusive, a Longvillian age for these Glanragon Beds is indicated.

Stratigraphically below the beds containing the above faunas, at SH 70805029 , a rather different faunal assemblage is present: Broeggerolithus sp. indet., Astroproetus aff. fearnsidesi (Bancroft), $F$. planimarginata, $B$. cf. minor (Salter), Brongniartella, sp., $B$. spiriferoides, Reuschella $\mathrm{cf}$. horderleyensis (Bancroft), Kjerulfina sp. Leptaena sp. and a strophomenid. Although this assemblage has both Longvillian and Soudleyan affinities, on balance a Soudleyan age appears more likely.

From the faunas present it can therefore be seen that the Glanrafon Beds immediately underlying the Snowdon Volcanic Series in the Dolwyddelan syncline are of Longvillian 
age. In Snowdonia, the Pitt's Head Rhyolite forms the base of the Snowdon Volcanic Series (Williams, H. 1927). East of the Glaslyn River it has been demonstrated that the Pitt's Head Rhyolite is Soudleyan in age (Williams, A. \& Harper in Beavon, 1963). This must mean that the Pitt's Head Rhyolite is missing from the succession in the Dolwyddelan area. According to Williams \& Bulman (1931, p. 434) the nearest recorded occurrence of the Pitt's Head Rhyolite is at Cerrig Cochion (Fig. 1) in the extreme west of the Dolwyddelan area but Beavon (1963) showed that the nearest outcrops of the lateral equivalent of the Pitt's Head Rhyolite (the Lower and Middle Lapilli Tuffs) crop out around Yr Arddu, approximately $4 \mathrm{~km}$ south-west of Cerrig Cochion.

The question remains as to which formation forms the base of the Snowdon Volcanic Series in the Dolwyddelan syncline. Williams \& Bulman suggested that the following succession was present there; Glanrafon Beds, Lower Rhyolite Tuffs, Bedded Pyroclastic Series and Upper Rhyolite Tuffs. Dean (1965) has shown that the Bedded Pyroclastic Series is Longvillian and Harper (in Shackleton, 1959) has dated the Lower Rhyolite Tuff of the Moel Hebog area as Lower Longvillian. The Glanrafon Beds discussed in this paper, which lie immediately under the Snowdon Volcanic Series, are also Longvillian in age; hence the authors are of the opinion that, on palaeontological grounds, the Lower Rhyolite Tuff is the most likely formation at the base of the Snowdon Volcanic Series in the Dolwyddelan syncline. This confirms the conclusion reached by Williams \& Bulman (1931, p. 440) on petrological grounds.

All the fossil specimens collected are lodged in the Department of Geology, University of Sheffield. The research for the above note has been carried out with the assistance of a University of Sheffield Field Research Fund (M.R.) and a N.E.R.C. research studentship (J.N.D.).

\section{REFERENCES}

BEAVON, R. V. 1963. The succession and structure east of the Glaslyn River, North Wales. Q. Il geol Soc. Lond, 119, 479-512.

DEAN, W. T. 1963. The Ordovician Trilobite faunas of South Shropshire, IV. Bull. Br. Mus. nat. Hist. (Geol.), 9, 1-18.

1965. A Shelly Fauna from the Snowdon Volcanic Series at Twll Ddu, Caernarvonshire. Geol. J., 4, pt. 2, 301-314.

SHACKLETON, R. M. 1959. The Stratigraphy of the Moel Hebog district between Snowdon and Tremadoc. Lpool Manchr geol. J., 2, 216-252.

WHITTARD, W. F. 1967. The Ordovician Trilobites of the Shelve Inlier, West Shropshire. Pt. IX. Palaeontogr. Soc. (Monogr), Lond., 307-352.

WHITTINGTON, H. B. 1966. The Ordovician trilobites of the Bala area, Merionethshire. Pt. III. Palaeontogr. Soc. (Monogr), Lond., 63-92.

- 1968. The Ordovician trilobites of the Bala area, Merionethshire. Pt. IV. Palaeontogr. Soc. (Monogr), Lond., 93-138.

WILLIAMS, A. 1963. The Caradocian brachiopod faunas of the Bala district, Merionethshire. Bull. Br. Mus. nat. Hist. (Geol), 8, 327-471.

WILLIAMS, H. 1927. The geology of Snowdon. $Q$. Jl geol. Soc. Lond., 83, 346-431. \& BULMAN, O. M. B. 1931. The Geology of the Dolwyddelan Syncline (North Wales). Q. Jl geol. Soc. Lond., 87, 425-458.

M. ROMANO,

DEPARTMENT OF GEOLOGY, UNIVERSITY OF SHEFFIELD.

J. N. DIGGENS, DEPARTMENT OF GEOLOGY, UNIVERSITY OF LIVERPOOL.

10th November, 1969.

\section{CORRELATION OF BASE OF MIDDLE HEADON BEDS BETWEEN WHITECLIFF BAY AND COLWELL BAY, ISLE OF WIGHT}

SIR,-The best exposures of the Middle Headon Beds (Lower Oligocene) of southern England are at Colwell Bay and Whitecliff Bay, on the western and eastern ends of the Isle of Wight. Away from the coast exposures are very limited and give no hope of 